\title{
a lenta trajetória da construção do porto de laguna
}

\author{
Alcides Goularti Filho* \\ Doutor em Economia pela UNICAMP. Professor do Departamento de Economia da Universidade \\ do Extremo Sul Catarinense. UNESC
}

\section{RESUMO}

O objetivo deste texto é discutir a evolução da construção e os projetos de melhoramentos e de reaparelhamento do porto de Laguna, no sul de Santa Catarina, seguindo a trajetória de porto da colonização, carvoeiro e pesqueiro. Além da introdução e da conclusão, o texto está dividido em seis tópicos: a) as percepções sobre o porto no século XIX, relatada por viajantes; b) o porto da colonização do sul-catarinense; c) a transformação em porto carvoeiro diante do projeto nacional de industrialização: d) as incertezas na definição do projeto, relatadas por seis engenheiros, nos anos de 1920, que apontavam as falhas no projeto de Francisco Calheiros da Graça,de 1882;e) a letargia do porto carvoeiro, que perdeu na disputa com o porto de Inibi tuba a exclusividade em escoar a produção de carvão; e f) a transformação em porto pesqueiro como unia solução paliativa para reverter a longa crise.

Palavras-chaves: Porto de Laguna - economia catarinense - projetos portuários

\begin{abstract}
The objective this text is to argue the evolution projects of improvements and equipment port of Laguna in the south of Santa Catarina being followed the trajectory of port of the colonization, coal and fishing. Beyond the introduction and conclusion, the text is divided five topics: a) the perceptions on the port in century XIX told by travellers; b) the transformation in coal port in the national project of industrialization; c) the uncertainties in the definition project told for six engineers in the years of 1920 they pointed the imperfections in the project of Francisco Calheiros da Graça 1882; d) the lethargy coal port that lost dispute with the port ot Imbituba the exclusiveness draining the coal production; e, e) the transformation port fishing as a palliative solution to revert long crisis.
\end{abstract}

Word-keys: Port of Laguna - catarinense economy - port projects

* Pesquisa financiada pelo CNPq e pela FAPESC. e-mail: alcides@unesc.net. Submetido: março, 2006; aceito: outubro, 2006. 


\section{Introdução}

O surgimento dos portos em Santa Catarina tem a ver com a demarcação, a ocupação e o povoamento do território catarinense. A instalação dos trapiches para ancorar as embarcações era condição necessária para a manutenção dos principais núcleos populacionais que foram surgindo ao longo do litoral de Santa Catarina. Durante todo o século XIV e a primeira metade do século seguinte, há vários registros de embarcações que atracaram na costa catarinense, umas seguiam adiante e outras desembarcavam expedições que seguiam para o interior. Mas, efetivamente, foi com a fundação das vilas de São Francisco do Sul, em 1658, Desterro (Florianópolis), em 1679, e Laguna, em 1682, que se iniciou um fluxo regular de embarcações, consolidando a importância dos três portos para demarcar o território no lado meridional da Colônia (CABRAL, 1994).

Laguna foi, durante todo o século XVIII, o ponto de convergência para as expedições que seguiam para o extremo sul da Colônia. Depois de Laguna, havia apenas Porto Alegre. A Estrada Real, aberta em 1738, que servia para o transporte de gados e muares da Colônia do Sacramento para a região das minas gerais, passava por Laguna e seguia para o planalto da capitania de Santa Catarina. Laguna consolidava-se como um centro comercial e difusor das conquistas da parte meridional da Colônia (CEAG/SC, 1980). O porto e a vila surgiram e se desenvolveram desta simbiose propagadora do comércio e das conquistas. A vila foi fundada às margens da Lagoa de Santo Antônio, na foz do Rio Tubarão, próximo ao mar. Rio, lagoa e mar criavam as condições físicas ideais para o desenvolvimento de um porto. Porém, a realidade foi sendo construída diferentemente da esperada por boa parte dos lagunenses; que sempre almejaram a construção de um grande porto para a cidade.

O Império herdou toda a estrutura portuária da Colônia,cujos portos e trapiches, espalhados ao longo da costa, não tinham condições de suportar o aumento do fluxo de carga. Durante o período colonial, as obras nos portos restringiam-se à construção de alfândegas, de cais e rampas-tocos. As alfândegas tinham como objetivo tão somente arrecadar mais impostos para a Coroa (CARVALHO, 1930). Desde o porto do Rio de Janeiro, passando por Salvador, Recife e Manaus até pe- 
quenos trapiches no sul do Império, todos necessitavam de melhoramentos, segurança e homens. Este será o eterno e grande problema para os portos brasileiros: a falta constante de investimentos e de recursos. Um problema que sempre foi solucionado temporariamente e que retornava em seguida, num grau de complexidade maior, exigindo mais investimentos e recursos. (GOULARTI FILHO, 2006). Durante o século XIX, os portos brasileiros eram de responsabilidade das Capitanias dos Portos, ligadas ao Ministério da Marinha. Com o aumento do fluxo de mercadorias exportadas e importadas, os portos passaram a ser de responsabilidade do Ministério da Viação e Obras Públicas (LISBOA, 1922).

O Brasil entrou, no último quartel do século XIX, fortalecendo as especializações regionais, pautadas na exportação de produtos primários. No Rio de Janeiro, iniciou-se a decadência da cafeicultora no Vale do Paraíba; em São Paulo, a grande marcha para o Oeste e a construção de ferrovias consolidavam a economia cafeeira; no Nordeste, a secular decadência do açúcar ensaiou um surto de crescimento com a introdução do vapor nos engenhos; no Norte, a borracha iniciava a sua trajetória ascendente; no Sul, podemos dividir em dois os complexos exportadores: a erva-mate no Paraná e a pecuária no Rio Cirande do Sul (FURTADO, 1989). Éramos uma economia agrária mercantil exportadora, ou seja, "voltada para fora". Portanto, o sistema de transportes predominante neste período, ferrovia e navegação fluvial, estava voltado para os portos.

Em Santa Catarina, durante todo o século XIX, os portos de Laguna, Florianópolis, Itajaí e São Francisco do Sul nunca tiveram expressão econômica nacional, sua importância era apenas local. Somente no final do século XIX é que os portos catarinenses passaram a ter mais destaque econômico (CUNHA, 1982). Durante a Primeira República, a divisão econômica dos portos catarinenses era a seguinte: Laguna e Imbituba exportavam carvão; Florianópolis, farinha; Itajaí, alimentos e madeira e São Francisco do Sul, erva-mate e madeira (LAGO, 1968). Mesmo assim, estes produtos não eram expressivos no conjunto da pauta de exportação brasileira, em que se destacavam café, borracha, algodão, cacau e açúcar.

O objetivo deste texto é discutir a lenta trajetória da construção do porto de Laguna, no sul de Santa Catarina, que, de porto das conquistas 
do sul da Colônia, passou para porto da colonização do sul de Santa Catarina, porto carvoeiro nacional, transformado em porto pesqueiro regional.Além desta breve introdução e da conclusão, o texto está divido em seis tópicos. Inicialmente, apresentaremos as percepções dos viajantes e dos pesquisadores que passaram por Laguna no século XIX e fizeram anotações sobre o porto e o problema na entrada da barra; em seguida, será discutida a integração do porto de Laguna com as colônias do sulcatarinense, escoando o excedente exportável; em terceiro lugar, a transformação de Laguna em porto carvoeiro; em seguida, serão relatadas as propostas de revisão do projeto inicial de construção do porto, em 1882; em quinto lugar, mostraremos a letargia do porto carvoeiro após 1945, que segue até final dos anos de 1960, quando Laguna é transformada em porto pesqueiro e, por último, serão discutidas as expectativas frustradas na transformação em porto pesqueiro.

\section{Percepções sobre o porto no século XIX}

Durante todo século XIX, Laguna foi uma cidade visitada por vários naturalistas, geógrafos e engenheiros, que se dirigiam para o interior da província ou seguiam viagem para o Rio Grande do Sul. O porto e a cidade foram relatados em várias memórias de viajantes. Nas de Paulo Joze Miguel de Brito (1829:35), membro da Academia Real de Ciências de Lisboa, escritas em 1816, sobre a Capitania de Santa Catarina, há a seguinte passagem sobre o porto de Laguna:

(...) [o porto] da Laguna, cuja barra é estreita, e não tem mais de 3 braças e meia de fundo; um banco de areia com alfaques a faz muito perigosa, e somente navegável para pequenas Sumacas; desde a barra até a Vila há uma légua, e aqui é o ancoradouro, que não tem mais de quatro braços de fundo.

Nos relatos de Augusto de Saint-Hilaire (1978: 199), que passou por Laguna em 1820, há as seguintes observações sobre a lagoa e o porto:

A lagoa denominada Laguna, à beira da qual fica situada a cidade do mesmo nome, foi talvez assim chamada por ter sido considerada provavelmente a maior lagoa da região [...] A lagoa recebe vários rios, sendo o mais notável o rio Tubarão, que é de grande importância para a travessia 
da barra à entrada da qual se lança as sua águas, e cujas margens são famosas por sua fertilidade.

Sobre o porto, Saint-Hilaire reconhecia que Laguna era "infinitamente menos interessante" do que os portos de São Francisco e Florianópolis, mas, era "bastante movimentado". Entre as embarcações que atracavam em Laguna, havia em torno de doze e eram de comerciantes locais. O viajante Ave-Lallemant (1980:35-36) fez a seguinte observação sobre o comércio e a navegação em Laguna no ano de 1858:

A Rua de Praia causa melhor impressão; embora não haja aqui especial vivacidade, sempre se vê movimento.Vêem-se pequenas embarcações ancoradas; em construção uma bonita e grande escuna de belas proporções. [...] E tanto quanto deixa ver um rápido olhar, sem dúvida se poderia fazer de Laguna um belo porto, de onde se poderia viajar parte por terra, parte ao longo das lagoas de Torres e estabelecer uma boa linha de comunicação, evitando a barra do Rio Grande.

Na descrição do Município de Laguna, feita por Francisco Isidoro Rodrigues da Costa, em 1881 (COSTA apud DALL'ALBA, 1976: 31), há o seguinte relato sobre o porto:

Existem nele várias pontes construídas de madeira e de pedras, as quais servem de trapiches onde se carregam e descarregam as embarcações. Não há na província município em que a navegação direta com a praça do Rio de Janeiro seja tão contínua e freqüente. O porto é vasto e abrigado. É um espetáculo magnífico quando no porto se acham 20 navios da parca e os iates em número superior a 40 .

O problema da entrada da barra, que tinha pouca profundidade, devido ao banco de areia ali formado, impedindo a entrada de navios de maiores calados, também foi relatado pelos viajantes. Saint-Hilarie (1978: 199) faz a seguinte exposição:

A lagoa de Laguna se estende na direção norte-sul, quase paralelamente ao mar, com o qual se comunica através de um canal estreito e de pequena extensão. Além de só ser possível transpor esse canal quando o vento sopra de uma determinada direção, as águas do mar estão constantemente revolvendo a areia que atravanca o seu fundo, e quando o Rio Tubarão deixa de 
lançar nessa passagem um volume de água considerável - o que sempre ocorre quando a seca se torna muito prolongada - as embarcações não podem sair.

Avé-Lallemant (1980:36) observou a seguinte paisagem:

A barra ao sul da cidade, na menor largura, mede apenas oito pés de profundidade, de modo que só dá entrada a navios de pequeno calado. A barra, todavia é menos variável que a do Rio Grande, porque o fluxo d'água da laguna e dos riachos que nela desembocam é mais estreito e concentrado do que no Rio Grande.

O porto das conquistas do extremo sul transformou-se no da colonização do sul catarinense, chegou a ser o porto carvoeiro do país, entrou num longo processo de letargia, tentou recuperar-se, incentivando a pesca, e hoje busca uma especialização, consolidando-se como porto pesqueiro.

\section{O porto da colonização sul-catarinense}

$\mathrm{Na}$ época da grande imigração, no último quartel do século XIX, parte do contingente de imigrantes que chegou ao Brasil destinou-se ao complexo cafeeiro paulista. O amplo sistema ferroviário paulista e o porto de Santos criaram condições concretas para a expansão da cafeicultura, que, por sua vez, permitia a fixação dos imigrantes nas fazendas e nas cidades (CANO, 1990). Para o Brasil meridional também foi destinado um razoável contingente de imigrantes para colonizar o Rio Grande do Sul - serra gaúcha e Vale do Rio dos Sinos - e Santa Catarina - litoral e planalto norte,Vale do Itajaí e sul. Em ambos os Estados, os novos imigrantes fundaram vilas e desenvolveram pequenas atividades mercantis. Com a ampliação de tais atividades, rapidamente as colônias se integraram comercialmente a outros centros urbanos maiores (CASTRO, 1980). Estradas, rios e ferrovias foram as vias de comunicação utilizadas pelos imigrantes para escoarem a produção das colônias.

A entrada de imigrantes em Santa Catarina, no século XIX, acelerou-se pós-1875, com a política imigratória financiada pelo governo imperial, principalmente de imigrantes alemães e italianos, em menor 
proporção poloneses, austríacos, portugueses, eslavos e espanhóis. Os alemães concentraram-se mais na região doVale do Itajaí e no norte; os italianos, no sul e também no Vale do Itajaí, e os poloneses, no Alto Vale do Rio Tijucas e no planalto norte (PIAZZA, 1994).

Para os imigrantes se instalarem, necessitavam basicamente de três suportes essenciais: financiamento governamental, terras disponíveis e companhias colonizadoras. A viagem e a instalação eram feitas por companhias colonizadoras privadas ou oficiais (estatais), que faziam contratos com o governo imperial, que se responsabilizava por financiálas. O sul catarinense foi ocupado, na sua grande maioria, por imigrantes provenientes do norte da Itália. Desembarcando em Florianópolis, descendo até Laguna e Tubarão, vão fazendo picadas mata adentro e ocupando terras devolutas já demarcadas para a colonização. Foram fundadas as seguintes vilas: Azambuja (1877), Urussanga (1878), Criciúma (1880), Cocai (1885), NovaVeneza (1890), Nova Belluno (1891) e Nova Treviso (1891) (DALL'ALBA, 1983).

$\mathrm{Na}$ colonização do sul-catarinense ocorreu o mesmo que no Vale do Rio Itajaí, onde pequenos proprietários, além da subsistência, produziam excedentes para a comercialização: produtos agrícolas manufaturados, como a farinha de milho, o arroz descascado, a farinha de mandioca, o açúcar, o pó de café, o vinagre e o vinho. Na pecuária, os produtos manufaturados era salame, banha, toucinho, torresmo, leite, nata, charque e outros. A presença de diversas e pequenas atividades mercantis e manufatureiras (artesanato e pequena indústria) formava um sistema colônia-venda, que contribuiu para gerar nas colônias uma acumulação pulverizada e lenta. Com a ampliação do sistema colônia-venda, começaram a surgir as primeiras casas comerciais e as pequenas oficinas de abrangência regional.Já nos anos de 1920, o excedente passou a ser exportado para praças comerciais maiores pelo porto de Laguna. As mercadorias eram comercializadas na hinterland e transportadas para o porto de Laguna, via Tubarão.

Nos primeiros tempos, ou seja, de 1910 a 1920, o transporte de mercadorias era feito com os carros de boi, daqui para Pontão, pouco depois de Jaguaruna,seguindo de lá,de canoa,para Laguna. De Laguna a Florianópolis, de navio, o Max, da Firma Hoepcke S.A. que tinha mais dois navios maiores. A firma Cooperativa Victória e a firma Giácomo Búrigo, de Mãe 
Luzia, e Bortoluzzi \& Irmãos, de Nova Veneza, exportavam banha, carne de porco salgada,feijão e outras mercadorias para o Rio (MILANEZ, 1990:29).

A relação que Joinville e as colônias do planalto norte tinham com o porto de São Francisco do Sul, dentro do complexo ervateiro, e a que Blumenau tinha com o porto de Itajaí, escoando a produção manufatureira, era a mesma que as colônias do sul tinham com o porto de Laguna. No início do século XX, todo o sistema de transporte no sul de Santa Catarina estava conectado com o porto de Laguna: ferrovia, canal de navegação e navegação marítima. A Estrada de Ferro Dona Tereza Cristina (E F D T ), ligando Araranguá, Criciúma, Urussanga, Lauro Muller e Tubarão ao porto de Laguna, além de transportar o carvão catarinense, contribuiu de forma significativa para integrar comercialmente a região com outros centros urbanos brasileiros. O trem de carga parava em todas as estações, carregando e descarregando mercadorias. As destinadas às exportações (mercado interno) tinham um destino certo: o porto de Laguna. O Canal de Navegação Fluvial Laguna-Jaguaruna passou a operar de forma mais racional a partir dos anos de 1920 , quando foram concluídas as obras de dragagem e a retilinização dos rios e das lagoas. Pelo Canal eram escoadas as mercadorias produzidas nas localidades mais próximas do litoral. O maior destaque era para o transporte de farinha de mandioca. A navegação marítima a vapor entre Araranguá e Laguna era feita pela Empresa Nacional de Navegação Hoepcke. Pelos seus navios, que saíam de Araranguá em direção a Laguna, eram transportadas as mercadorias produzidas na região do Vale do Araranguá (FREITAS, 2006).

\section{Transformando no porto carvoeiro}

No início da República, o complexo cafeeiro estava em franca expansão, principalmente com a construção das ferrovias que cortavam todo o interior paulista, ligando-as ao porto de Santos. A cidade de São Paulo se estava urbanizando rapidamente e a chegada de mais e novos imigrantes mudava o cotidiano na capital paulista, nas lavouras e nas fazendas de café no interior (SAES, 1986). No Norte do país, a borracha era o grande produto de exportação, que formava um grande complexo extrativista, integrando a região à economia mundial. No Nor- 
deste, apesar da longa e lenta decadência da economia açucareira, a mecanização de alguns engenhos ensaiava um novo impulso econômico para a região. No Maranhão, ainda resistia a lavoura de algodão e, no sul da Bahia, o cacau estava expandindo-se. No Brasil meridional, destacavam-se a pecuária de corte no sul do Rio Grande do Sul e a erva-mate no norte de Santa Catarina e no sul do Paraná (CANO, 1990). $\mathrm{Na}$ verdade, este é o movimento geral e maior da economia brasileira na época em que havia uma estreita ligação com o desenvolvimento dos portos brasileiros: a borracha em relação ao porto de Manaus, a cana-de-açúcar em relação ao de Recife, o algodão em relação ao de Maranhão, o cacau em relação ao de Salvador, o café em relação ao de Santos, a erva-mate em relação ao de Paranaguá e São Francisco do Sul e o charque em relação ao de Rio Grande (LISBOA, 1922). Ao mesmo tempo em que se expandiam as exportações, também cresciam as importações. A construção das ferrovias vai justamente dar suporte para estes complexos (excluindo a borracha), integrando as regiões produtoras aos principais portos. Com tantas demandas, maiores eram as exigências para o melhoramento dos portos brasileiros.

O porto de Laguna estava fora do amplo espectro desta especialização portuária nacional. Porém, com a descoberta do carvão mineral no sul de Santa Catarina, foram dadas as condições materiais para tornar Laguna num grande porto carvoeiro, o único do país. A constatação de que havia carvão mineral no sul de Santa Catarina nos remete ao início do século XIX. O governo da Província de Santa Catarina, em 1837, oficializou a descoberta do carvão em território catarinense por meio do relatório expedido pela Câmara de Laguna, afirmando que havia sido descoberto carvão mineral em grande quantidade na localidade de Lajeado do Cedro (SANTA CATARINA, 1837). Dois anos após, o governo provincial reforçou o feito da descoberta, sugerindo que fosse construída uma estrada de ferro ligando as minas aos lugares de embarque do carvão. Para tanto, deveria ser organizada legalmente uma companhia para explorar as minas (SANTA CATARINA, 1839). Os estudos realizados comprovavam a boa qualidade do carvão, porém apontavam dificuldades para o transporte até o porto de embarque. O secular porto de Laguna era, talvez, a única alternativa mais próxima, porém o problema na entrada da barra inviabilizava a passagem de navios de grande calado que, inicialmente, deveriam 
trazer os pesados materiais para a construção da ferrovia e, em seguida, exportar o carvão.

Em 1860, o Visconde de Barbacena contratou James Johnson, profissional de mineração, para fazer una amplo estudo sobre as minas catarinenses. Os estudos seguiram até o ano de 1862 e, neste intervalo, o governo imperial concedeu a Barbacena, por meio do Decreto ${ }^{\circ} 2.737$, de 6 de fevereiro de 1861, o direito de lavrar as minas de carvão de pedra nas margens do Passa Dois, distrito de Laguna. A previsão inicial era fazer uma ligação ferroviária da cabeceira do Rio Tubarão, região das minas, até o porto de Laguna, mas as dificuldades apresentadas na entrada da barra levaram Barbacena a buscar uma nova alternativa (BRASIL, 1861). A Enseada de Imbituba, onde havia a armação baleeira, tinha um bom ancoradouro natural, mas também tinha o problema do regime dos ventos norte e nordeste, que dificultariam a atracação dos navios. A única solução viável seria a construção de um quebra-mar. Esta indecisão na escolha do melhor porto para escoar o carvão catarinense deu início a uma longa disputa entre os portos de Laguna e Imbituba para serem escolhidos como porto carvoeiro. No projeto final, ficou definido que a ferrovia ligaria a região das minas, na cabeceira do Rio Tubarão, ao porto de Imbituba, com um ramal até o de Laguna.

Com a chegada da ferrovia a Laguna, estava-se definindo a futura especialização do porto da cidade: tornar-se um porto carvoeiro. O problema era que Imbituba também vislumbrava consolidar-se como tal. Distantes apenas 28 quilômetros um do outro, seria inviável manter neste pequeno raio de abrangência dois portos carvoeiros.

Tomaremos, como referência para início das análises sobre as obras no porto de Laguna, o estudo elaborado pelo capitão-tenente Francisco Calheiros da Graça, em março de 1882, designado pela Repartição Hidrográfica do Ministério da Marinha para realizar um estudo sobre as barras de Laguna e Itajaí. Segundo o Barão de Teffé, no prefacio do projeto elaborado por Calheiros da Graça, o estudo atendia "as reclamações constantes dos povos de Laguna" e provava que Laguna era mais viável que Imbituba (GALHEIROS DA GR A ÇA, 1882: 5). Este estudo serviu como referência para todas as obras executadas na barra da Laguna, na primeira metade do século XX. Neste mesmo período (1880-1884), os ingleses estavam construindo a EFDTC e o porto de Imbituba. Os comerciantes lagunenses, temerosos da possibilidade de verem 
cair o movimento comercial na cidade, solicitaramjunto ao governo imperial um projeto de obras para solucionar o problema da entrada da barra. Além do mais, não era de agrado do governo imperial que os ingleses construíssem um novo porto no sul de Santa Catarina. A intenção era que fosse solucionado o problema da barra de Laguna, que os ingleses julgavam instransponível (GREENHALGH, 1882).

Segundo as observações de Calheiros da Graça, este banco era formado por uma areia fina, que se deslocava devido ao impulso das águas e que, aumentando a velocidade da água que entra no oceano, o banco seria removido. Para tanto, as obras previstas por Calheiros da Graça eram as seguintes (1882: 24):

Correr um quebra-mar que partindo da ponta do Pontal vá buscar o banco, atravessando o largamar pela sonda de seis metros, até a posição marcada na planta junto com a profundidade de quatro metros, daí inclinar-se um pouco para o sul até encontrar o fundo de sete metros, já muito além do banco, e onde dominam as correntes gerais da costa. A sua extremidade deverá ficar na distância de 380 metros da ponta do Tamborete e terá para comprimento total 1.100 metros.

Com estas obras, não haveria mais a "reprodução dos mesmos bancos na nova barra" (CALHEIROS DA GRAÇA, 1882: 24). No ano seguinte, após a publicação dos Estudos Sobre a Barra da Laguna, no dia 25 de julho de 1883, foi publicado um artigo assinado com o pseudônimo de "O Progresso", noJornal do Commercio do Rio de Janeiro, discordando dos resultados apresentados por Calheiros da Graça. Segundo o artigo, Calheiros da Graça ficou apenas uma semana em Laguna e confiou nas informações repassadas pelos moradores locais de que a construção de um quebra-mar mudaria o regime no porto e permitiria a entrada de navios maiores. Em seguida, foi publicado outro artigo anônimo, assinado por "O Lagunense Imparcial", questionando o valor orçado. A partir destes dois artigos, começa uma série de acusações e defesas, feitas entre os dois anônimos e Calheiros da Graça. Segundo informações dos comerciantes de Laguna, na verdade, quem assinava os artigos anônimos era o "encarniçado inimigo" de Laguna, o engenheiro fiscal da Estrada de Ferro Dona Teresa Cristina, João Carlos Greenhalgh, defendendo os interesses dos ingleses que pleiteavamjunto ao governo a construção do quebra-mar em Imbituba, para proteger o 
porto dos ventos (CALHEIROS DA GRAÇA, 1883). Este episódio marcou o início de uma longa disputa entre os portos de Laguna e Imbituba, que se arrastou até os anos 1950.

Tendo como referência os estudos de Calheiros da Graça, pelo De creto $\mathrm{n}^{\circ} 1.034$, de 14 de novembro de 1890, ficou concedido à Companhia Industrial e de Construção Hidráulica o privilégio, por 40 anos, com garantia dejuros de $6 \%$ ao ano, durante 30 anos, para a construção, uso e gozo das obras de melhoramento da barra e do porto de Laguna. Num prazo de 12 meses, a companhia deveria apresentar ao governo os estudos das obras e das instalações exigidas pelo contrato, com os respectivos orçamentos. Depois de aprovados o projeto e o orçamento, as obras deveriam começar no prazo de um ano.

Após 14 anos de espera e sem uma definição da companhia, o De creto $\mathrm{n}^{\circ} 5.228$, de 31 de maio de 1904, declarou sem efeito o privilégio concedido à Companhia Industrial e de Construções Hidráulicas. Este decreto foi aprovado quando o ministro daViação e Obras Públicas era o catarinense Lauro Müller. Imediatamente após o fim dó privilégio, em 1904, a Comissão do Porto de Santa Catarina efetivamente começou as obras na barra e no porto (BRASIL, 1904). A construção do molhe exterior norte iniciou-se em dezembro de 1905, no mesmo ano em que começaram as obras do porto de Itajaí, cidade natal de Lauro Müller.Todo o crédito disponível foi utilizado nos diversos trabalhos iniciais das obras, além do concedido pelo governo do Estado de Santa Catarina (BRASIL, 1905). As obras a serem realizadas pela Comissão do Porto de Santa Catarina eram:

1) Um molhe quebra-mar enraizado no pontal norte da barra através do banco, destinado a estreitar a seção de vazão da corrente [...] e deverá ter a extensão de $1.300 \mathrm{~m}$. [...] dois alinhamentos: o primeiro com $950 \mathrm{~m}$ orientado para o rumo leste e o segundo virado um pouco para o norte.

2) Um guia-corrente paralelo ao pontal e formando o lado interno do canal de acesso ao porto com $450 \mathrm{~m}$.

3) O revestimento da margem esquerda com espigão na extensão de mais $400 \mathrm{~m}$. (LISB OA, 1922: 276-277).

O ritmo das obras seguiu satisfatoriamente até 1914, como pode ser acompanhado na Tabela 1, quando os trabalhos foram suspensos em função da crise financeira e da Primeira Guerra Mundial (MINISTÉRIO 
DA VIAÇÃO E OBRAS PÚBLICAS, 1918). A mudança mais importante foi na profundidade da entrada da barra, que passou de 2,35 m em 1905 para 4,48 em 1913. No ano de 1918 , o Congresso autorizou a continuação das obras e liberou mais verbas para o reinício dos trabalhos.

Neste mesmo período, podemos pensar a economia catarinense durante as primeiras décadas do século XX, como a fase de origem e crescimento do capital industrial; nele, predominava a pequena produção mercantil, a extração da erva-mate, da madeira e do carvão, as indústrias têxtil e alimentar. A erva-mate extraída, transportada e beneficiada em Santa Catarina fazia parte do grande complexo ervateiro do Paraná. Parte da sua produção era escoada pelos rios Iguaçu e Negro, seguindo pela Estrada Dona Francisca e pelo ramal ferroviário da Estrada de Ferro São Paulo-Rio Grande até a cidade de Joinville, onde era beneficiada, para, depois, ser despachada pelo porto de São Francisco. Este complexo começou a ser desmontado após 1930, com a queda nas exportações da ervamate. A madeira, basicamente a araucária, era extraída no oeste catarinense e escoada pelo Rio Uruguai, para a Argentina, e pela Estrada de Ferro São Paulo-Rio Grande. Quando se esgotaram as reservas florestais da região, a partir dos anos de 1940 , as atividades madeireiras deslocaram-se para o planalto serrano. O carvão era extraído das minas no sul catarinense e transportado pela Estrada de Ferro Dona Tereza Cristina até os portos de Laguna e Imbituba. Os alimentos e os têxteis concentravam-se nas cidades de Blumenau e Brusque, que comercializavam com várias cidades catarinenses e de outros estados. Como conclusão deste movimento maior, podemos olhar para Santa Catarina neste período como uma economia especializada em que cada porto atendia à sua hinterland, reforçando a especialização (G O ULARTI FILHO, 2002; KROETZ, 1975).

Se pensarmos o sistema portuário nacional neste período, a Primeira República herdou do Império um sistema portuário fragmentado e em precárias condições, com portos e trapiches espalhados ao longo da costa, sem condições de suportar o aumento do fluxo de carga. Desde o porto de Manaus, passando por Recife, Salvador, Rio de Janeiro e chegando até os pequenos trapiches no sul do país, todos necessitavam de melhoramentos, segurança e recursos humanos. Durante o período de 1910 a 1934, que foi caracterizado pelo início da nacionalização do problema portuário, com a centralização das tomadas de decisões, podemos destacar dois avanços para os portos: a criação da Inspetoria Federa! 
dos Portos, Rios e Canais (IFPRC), em 1910, e a aprovação do Regulamento dos Portos Organizados, em 1922. Quando da aprovação do Regulamento, mesmo tendo como móvel da acumulação o capital mercantil agrário e exportador, a economia brasileira passava por um processo de diversificação econômica.Tais condições concretas rebatiam na estrutura portuária já deficiente, que contribuía para agravar ainda mais a situação precária dos portos (GOULARTI FILHO, 2006).

\section{Incertezas na definição do projeto}

Nos anos 1920, seis engenheiros, Edgard Gordilho (1922), Cândido Lucas Gaffrée (1924), J. D. Belfort Vieira (1924), Luiz J. Lê Cocq de Oliveira (1925), Lucas Bicalho (1926) e Alfredo Lisboa (1922), elaboraram estudos minuciosos, apontando os erros na execução nas obras na barra do porto de Laguna, cuja base do projeto tinha sido elaborado por Francisco Calheiros da Graça, em 1882, e realizada pela Comissão dos Portos de Santa Catarina.

Para Calheiros da Graça (1882), o maior problema a resolver na barra era fixar o pontal de areia. O objetivo era aumentar a velocidade das águas, vindas da Lagoa de Santo Antônio, que desobstruiria a sua entrada, aumentando a profundidade. Acrescido da fixação das dunas, em boa medida, este foi o projeto seguido até meados dos anos de 1920. Nos anos seguintes, as obras prosseguiram, lentamente, sem reverter o problema estrutural, que se concentrava na curvatura dos molhes, impedindo o aumento da profundidade da barra. E erajustamente na "lentidão das obras" do molhe que residia o problema, fruto da falta de recursos.

O engenheiro Edgard Gordilho, no seu estudo realizado em junho de 1920, não estava satisfeito com os resultados das obrasjá executadas. Para ele, as deficiências existentes não exigiam novas providências, eram resultados apenas da "míngua de recursos da Comissão", que deveriam ser aumentados. A estrutura da barra da Laguna era a mesma da do porto do Rio Cirande, no entanto, o problema foi solucionado, dados os vultosos recursos investidos, uma vez que o porto era o mais importante do Estado e escoava boa parte da produção agrícola e pecuária, principalmente o charque e o couro, do Rio Grande do Sul. Como Laguna era tão simplesmente um porto local, não interessava à economia 
nacional e aos capitalistas investirem grande soma de dinheiro num porto pouco expressivo. Gordilho argumentava que o maior problema era a falta de recursos financeiros. A paralisação das obras em 1914 e a lenta recuperação após 1918 tornavam cada vez mais difícil resolver o problema da baixa profundidade na entrada da barra (GORDILHO apud MINISTÉRIO DAVIAÇÃO E OBRAS PÚBLICAS, 1922).

O engenheiro Cândido Lucas Gaffrée, em fevereiro de 1923, publicou o "Estudo e Projeto do Porto de Laguna", que recomendava mudanças no projeto que estava sendo executado, por conter um erro técnico. Como a obra já estava bem adiantada, tendo o molhe norte, no ano de 1923, em torno de 844 metros, desmanchá-lo não seria fácil. $\mathrm{Na}$ verdade, para Gaffrée, o "projeto executado foi um completo insucesso" (GAFFRÉE apud MINISTÉRIO DA VIAÇÃO E OBRAS PÚBLICAS, 1924:212). Laguna corria o risco de deixar de escoar a produção de carvão ejá se cogitava a construção de um porto carvoeiro mais ao norte, em Massiambu, próximo de Florianópolis.

Segundo J. D. Belfort Vieira, no relatório sobre o porto de Laguna, apresentado emjulho de 1923 à IFPRC, havia opiniões de profissionais "quejulgam ter se dado um erro técnico inicial no projeto de melhoramento da barra de Laguna" (VIEIRA apud MINISTÉRIO DAVIAÇÃO E OBRAS PÚBLICAS, 1924: 232). Segue Vieira (1924: 232): "não sendo fácil desmanchar a obra feita, não há como procurar outro porto para resolver a questão da exportação do carvão nacional".Vieira também citou exemplos de outras barras que tinham a mesma estrutura que a de Laguna e que obtiveram resultados positivos, como a de Liffey, na entrada do porto de Dublin, e a do Danúbio.

No relatório da "Viagem de inspeção aos portos do Estado de Santa Catarina", em 1923, Cocq de Oliveira discorda de Calheiros da Graça quanto à origem do banco de areia, que, para Calheiros da Graça, era formado pela descarga dos rios, cujo escoadouro era a própria barra.Já para Cocq de Oliveira, o banco de areia tinha origem marítima, portanto, o molhe deveria ter outro formato (COCQ DE OLIVEIRA apud MINISTÉRIO DAVIAÇÃO E OBRAS PÚBLICAS, 1925).

O relatório elaborado pelo engenheiro Lucas Bicalho, em agosto de 1925, novamente denunciava o grave problema da barra. Especificamente sobre o porto, Bicalho condicionava primeiramente a resolução deste problema. A abertura da barra aumentaria a corrente que mante- 
ria o fundo, porém a velocidade observada não era suficiente para provocar erosões apreciáveis. Para uma solução mais plausível, Bicalho sugeria três providências: a) retificar o canal de acesso ao porto; b) fixar as dunas da praia norte da barra; c) reforçar a raiz do molhe (BICALHO apud MINISTÉRIO DA VIAÇÃO E OBRAS PÚBLICAS, 1926).

E, por último, em 1928, numa tentativa hercúlea de querer resolver o problema, a Inspetoria designou o renomado engenheiro Alfredo Lisboa para realizar um novo estudo sobre a barra e apresentar uma proposta definitiva. É bom lembrar, o ministro daViação e Obras Públicas era o catarinense Victor Konder. Lisboa, com base nas técnicas de H. C. Ripley e na planta levantada por Lucas Bicalho em 1926, propôs o prolongamento do molhe, em reta, até atingir 1.025 metros, daí em diante em curva de 1.000 metros de raio, com a convexidade virada para NE, até atingir a isóbata de 8 metros, além da construção de novos guias correntes (MINISTÉRIO DA VIAÇÃO E OBRAS PÚBLICAS, 1937:1936).

Esta proposta foi apresentada anexada ao Decreto $\mathrm{n}^{\circ} 18.281$, de 15 de junho de 1928, que aprovou o projeto e o respectivo orçamento. Foi contratada a Companhia de Mineração e Metalurgia do Brasil (COBRASIL) para executar as obras, que também ficou responsável pela retomada das obras do porto de Itajaí. Mal recomeçaram as lentas obras, foram, em seguida, paralisadas em 1930, com as do porto de Itajaí, bem como aberta uma sindicância para investigar irregularidades junto à COBRASIL. No ano de 1938, foi elaborado um novo contrato com a COBRASIL para conclusão das obras do porto de Itajaí e Laguna.

Novamente, em 1938, dada a necessidade de escoar o carvão nacional, foi apresentado ao Departamento Nacional de Portos e Navegação (DNPN - sucessor do IFPRC) um novo projeto coordenado pelo engenheiro Thiers de Lemos Fleming para retomar as obras no porto de Laguna e solucionar o eterno problema da entrada da barra. Inicialmente, Fleming constatou que, à medida que o molhe avançava,"caminhava também, na mesma direção, o banco de areia, provocando o deslocamento para o largo das isobatas maiores de 5,00 metros" (MINISTÉRIO DA VIAÇÃO E OBRAS PÚBLICAS, 1939: 32). Aplicar o método H. C. Ripley necessariamente exigia "um conhecimento nítido do regime do curso da água". E erajustamente o que faltava nos projetos de melhoramento dos portos de Itajaí e Laguna. 
Tabela 1 - Evolução dos trabalhos realizados na barra da Laguna 1904-1943

\begin{tabular}{|c|c|c|c|}
\hline ANO & $\begin{array}{l}\text { EVOLUÇÃo DA CONSTRUÇão } \\
\text { DO MOLHE NORTE (em metros) }\end{array}$ & $\begin{array}{l}\text { TONELADAS DE } \\
\text { PEDRA }\end{array}$ & $\begin{array}{l}\text { PROFUNDIDADE DA } \\
\text { ENTRADA DA BARRA }\end{array}$ \\
\hline 1904 & - & 9.256 & - \\
\hline 1905 & 136 & 10.717 & 2,35 \\
\hline 1906 & 332 & - & 2,89 \\
\hline 1907 & 396 & 27.827 & 3,13 \\
\hline 1908 & 532 & 29.131 & 3,90 \\
\hline 1910 & 588 & 26.013 & - \\
\hline 1911 & 660 & 28.037 & 3,89 \\
\hline 1912 & 684 & 22.112 & - \\
\hline 1913 & 700 & 18.784 & 4,48 \\
\hline 1914 & 724 & 16.716 & - \\
\hline 1916 & - & 10.000 & 4,68 \\
\hline 1917 & - & 7.000 & 4,50 \\
\hline 1918 & - & - & 4,50 \\
\hline 1919 & - & 14.691 & 4,30 \\
\hline 1920 & 785 & 6.790 & 4,50 \\
\hline 1921 & 798 & - & 3,88 \\
\hline 1922 & 844 & 2.425 & - \\
\hline 1926 & - & 20.695 & - \\
\hline 1927 & 914 & - & - \\
\hline 1928 & 979 & - & 3,10 \\
\hline 1936 & 1.246 & 153.464 & 4,00 \\
\hline 1937 & 1.357 & 103.493 & 5,00 \\
\hline 1940 & - & 319.478 & 5,50 \\
\hline 1941 & - & 275.712 & 5,50 \\
\hline 1942 & - & 270.757 & 6,00 \\
\hline 1943 & & 202.669 & 6,38 \\
\hline
\end{tabular}

Fonte: Relatórios do Ministério da Viação e Obras Públicas; Inspetoria Federal de Portos, Rios e Canais; Departamento Nacional de Portos e Navegação; Departamento Nacional de Portos, Rios e Canais. 
O Decreto ${ }^{\circ} 2.794$, de 25 dejunho de 1938 , aprovou novo projeto e orçamento para as obras de melhoramento no canal de acesso ao porto de Laguna. Durante os anos da Segunda Guerra, as obras seguiram um ritmo acelerado, obedecendo ao projeto de Fleming e ao método H. C. Ripley, proposto por Lisboa. Na verdade, em boa medida, as obras na barra seguiram o erro inicial do projeto de Calheiros da Graça, de 1882 . Na tabela abaixo, podemos acompanhar a evolução das obras no porto e na barra de Laguna de 1904 a 1943.

A partir dos anos de 1930 , a política portuária brasileira tomou outro rumo. Em 1930, o inspetor Hidelbrando de Araújo Góes publicou um livro/relatório que expressou bem o espírito de mudança da época, pautado numa maior atuação do Estado na economia e na centralização das tomadas de decisões. Segundo Góes, o governo federal deveria abandonar a velha política de pensar o melhoramento dos portos, que era fragmentada e desarticulada, para pensar uma nova, centralizada e hierarquizada. A falta de "planejamento" de uma política portuária nacional levou à superabundância de diversos portos na costa brasileira, construídos de forma aleatória e sem relação econômica com a sua hinterland. Cada estado, além de pleitear o melhoramento de seu porto principal, para atender a interesses locais, defendia a construção de novos portos para levar em conta demandas específicas. Muitas vezes, era ignorada a presença de um porto no Estado vizinho, que facilmente poderia atender às demandas específicas para contemporizar os compromissos políticos. Góes defendia que os portos deveriam ser classificados numa hierarquia, destacando os principais portos organizados e sua grande área de abrangência. Os pequenos portos tributários deveriam ter um caráter "nitidamente temporário", e seu funcionamento dependeria da "marcha evolutiva das necessidades de cada um deles" ( GÓES, 1930:7). Esta foi a visão que norteou a política portuária brasileira nas décadas seguintes.

O Estado que surgiu após a Revolução de 1930, além de ampliar a sua base de atuação, passou a centralizar, burocratizar e racionalizar ainda mais as suas funções (D R A I B E, 1985). Do ponto de vista econômico, os anos de 1930 inauguram também um novo padrão de acumulação, o da industrialização restringida. Já podemos falar em industrialização, porém ela é limitada pela baixa capacidade de importar e pelas débeis bases técnicas e financeiras, cuja acumulação era horizontal, incapazes, 
portanto, de comandar e financiar os investimentos necessários para o país constituir "forças especificamente capitalistas de produção" (CAR DOSO DE MELLO, 1988). Um país em ritmo acelerado de industrialização exigia portos mais equipados.

\section{A letargia do porto carvoeiro}

Entre o longo período de 1930 a 1980, temos que pensar a evolução dos portos dentro do "projeto nacional de industrialização", comandada pelo Estado. Durante todo este tempo, passamos por vários regimes políticos, mas, até 1980 , seguiu ininterruptamente um processo de industrialização acelerada. O Estado brasileiro assumiu formas superiores de organização capitalista, orientando o processo de acumulação por meio do planejamento e do financiamento, além de políticas cambiais (orçamento cambial) e monetárias mais flexíveis, voltadas para o crescimento. O Plano de Metas (1956-1961) e o II Plano Nacional de Desenvolvimento (1975-1978) são dois exemplos que cristalizaram os objetivos do Estado para a formação de um sistema nacional de economia (TAVARES, 1998). Do ponto de vista institucional, ocorreram quatro mudanças: a criação do Departamento Nacional de Portos e Navegação (DNPN) em 1934, alterado em 1943 para Departamento Nacional de Portos, Rios e Canais (DNPRC), transformado em autarquia em 1963, como Departamento Nacional de Portos e Vias Navegáveis (DNPVN) e em Empresa de Portos do Brasil S.A. (Portobrás) em 1975, u ma empresa holding.

Com o advento da Segunda Guerra Mundial, o carvão catarinense passou a ter prioridade na política nacional de melhor aproveitamento dos recursos nacionais. Para defendê-1o, foram editados vários decretos, inclusive encampando toda a produção de carvão das companhias privadas. Com isto, a produção bruta de carvão em Santa Catarina passou de 171.010 toneladas em 1938 para 815.678 em 1945 (MORAES, 2003). No Decreto $\mathrm{n}^{\circ}$ 4.676, de 1939, Getúlio Vargas definiu que as obras do porto de Laguna deveriam ser realizadas "para dar franco escoamento ao carvão do Estado de Santa Catarina", transformando o porto de Laguna num porto carvoeiro. Porém, foi com a construção da Companhia Siderúrgica Nacional (CSN), em Volta Redonda, que o carvão catarinense passou a ser mais bem aproveitado. Com relação à opção do governo 
federal em definir qual seria o porto carvoeiro (Laguna ou Imbituba), naquele momento do conflito mundial, do ponto de vista da segurança nacional, seria mais estratégico investir num porto público, como era o de Laguna, do que num porto privado, como era o de Imbituba.

Dentro dos objetivos da industrialização nacional e para atender às demandas nacionais de carvão, entre 1939 e 1944, as obras da construção do novo porto em Laguna seguiram num ritmo bastante acelerado, quando foi transferido definitivamente da Rua da Praia para a Ponta do Magalhães. A movimentação de exportações de cabotagem no porto teve um aumento exponencial, passando de 15.554 toneladas em 1938 para 158.626 em 1945 e, durante a guerra, o movimento de longo curso foi suspenso em Laguna. A razão da construção do novo porto de Laguna era a sua inserção dentro de um projeto de industrialização, escoando a produção de carvão. Fora disto, obedecendo às recomendações do inspetor Hidelbrando de Araújo Góes, não interessava ao governo federal fragmentar ainda mais o sistema portuário nacional.

O Decreto-Lei $n^{\circ} 5.460$, de 6 de maio de 1943, organizou a autarquia Administração do Porto de Laguna (APL), que tinha como objetivo "a exploração industrial e comercial e os melhoramentos do porto de Laguna". Porém, a $A V L$ teve vida curta e, em 1946, pelo Decreto ${ }^{\circ}$ 8.848 , de 24 de janeiro, a autarquia foi dissolvida e a administração do porto passou a ser de responsabilidade do $17^{\circ}$ Distrito de Fiscalização de Santa Catarina, subordinado ao DNPRC. O fim da Guerra, cessando o movimento de exportação de carvão, que basicamente foi transferido para o porto de Imbituba, marcou o início da longa regressão do porto de Laguna. No preâmbulo do Decreto $\mathrm{n}^{\circ}$ 8.848, que dissolveu a APL, há a seguinte exposição de motivos:

- Considerando que o regime autárquico, em face da pequena receita portuária, apresentada pela exploração comercial do Porto de Laguna, tem causado déficits sucessivos a essa autarquia, advindo, daí, embaraços administrativos à mesma.

- Considerando ainda que a interrupção na exploração do referido porto redundará em graves prejuízos para a exploração do carvão nacional de Santa Catarina e que a exploração sob regime deficitário traria dificuldades à conservação do aparelhamento portuário existente no aludido porto. 
- Considerando, por fim, que a experiência tem demonstrado a inconveniência da exploração do Porto de Laguna por um órgão de natureza autárquica. (DECRETO $\mathrm{n}^{\circ} 8.848 / 1946$ ).

Segundo o Relatório do Ministro daViação e Obras Públicas, Maurício Joppert da Silva, de 1946, o Porto de Laguna funcionava sob "regime deficitário permanente, não podendo atender aos seus encargos normais, nem tão pouco às solicitações de aumento de vencimento pessoal" (BRASIL, 1946: 159). Em 1946, foram abertos no Ministério dois créditos especiais para atender às despesas do porto, mostrando claros sinais de insustentabilidade financeira. É bom lembrar que, nesse momento, já estava em pleno funcionamento o porto de Imbituba, que começava a se consagrar como o único porto carvoeiro do país. Para alívio do governo que almejava cortar gastos, Imbituba funcionava sob o regime privado. Após 1945, reacendeu a disputa entre os portos de Laguna e Imbituba, só que, desta vez, Imbituba, ao contrário dos anos 1940, saiu beneficiada. O novo porto carvoeiro de Laguna teve vida curta. Com isto, Laguna foi excluída dos projetos nacionais de industrialização.

No final de 1945, as instalações portuárias em Laguna eram as seguintes: um cais acostável com 300 metros de extensão e com profundidade de 8 metros, um armazém com $1.600 \mathrm{~m}^{2}$, três carvoeiras com capacidade para 45.000 toneladas, quatro guindastes elétricos (2 para meia tonelada e 2 para 8 toneladas), um rebocador com força de 150 HP e uma pequena usina termoelétrica (MINISTÉRIO DAVIAÇÃO E OBRAS PÚBLICAS, 1949: 134).

Com a consolidação do porto de Imbituba como o único carvoeiro, após 1945, Laguna entrou num longo processo de letargia, que seguiu até 1980, quando foi reinaugurado como porto pesqueiro. Durante todo este período, atracaram principalmente pequenas embarcações pesqueiras e, como não foram feitas as devidas manutenções, principalmente na entrada da barra, a profundidade foi diminuindo a cada ano que passava, inviabilizando a exploração comercial do porto.

O fim da APL marca o início de uma série de projetos e propostas elaboradas pelos superintendentes do porto de Laguna na tentativa de recuperá-1o. Em março de 1956, o Laboratoire Central D'Hydraulique de France, a pedido do DNPRC, realizou estudos nos portos de Lagu- 
na e Imbituba. Em Laguna, foi feito um estudo com modelo reduzido, e foram realizados estudos dos fenômenos naturais, do acesso à barra, da ratificação do acesso à barra, da profundidade máxima possível do canal e da solução definitiva (LABORATOIRE CENTRAL D'HYDRAULIQUE DE FRANCE, 1956). Com relação ao molhe, o Laboratoire recomendava que deveria ser feita uma retificação no molhe sul com orientação para o leste. No ano seguinte, Colombo Machado Salles, que era responsável pelo porto de Laguna, encaminhou a o DNPR um relatório, analisando as conclusões do Labotaroire, afirmando que elas deixavam "muito a desejar e dele quase nenhum proveito pode se tirar" para entender a dinâmica dos fenômenos fluviais e marítimos que operam na barra e no canal do porto de Laguna (DEPARTAMENTO NACIONAL DE PORTOS, RIOS E CANAIS, 1957:5). Quanto ao porto de Imbituba, Salles afirmava que deveriam ter sido elaborados estudos complementares indispensáveis.

Em 1962 e 1967, foram realizados dois novos estudos na barra e no canal, com intuito de reverter o eterno problema do assoreamento. Com base no relatório de Salles, em 1970, o DNPVN publicou "Relatório diagnóstico e analítico sobre os estudos para a melhoria do acesso e aprofundamento da barra da Laguna". Neste relatório, foram apresentadas novas alternativas para corrigir o erro na entrada da barra. Como as obras não foram executadas, a única solução seria definitivamente transformá-lo num porto pesqueiro público, o que veio a ocorrer em 1969. A linha férrea foi completamente abandonada, os guindastes não foram mais utilizados e o movimento caiu vertiginosamente, inviabilizando financeiramente o porto. Para se ter uma idéia, a arrecadação dos anos de 1960 a 1965 foi de Cr\$30.395,812,00 e as despesas com pessoal, apenas do mês de dezembro de 1965, foram de Cr\$32.267.632,00 (DEPARTAMENTO NACIONAL DE PORTOS E VIAS NAVEGÁVEIS, 1966: 30-31).

$\mathrm{Numa}$ perspectiva mais ampla, paralela aos planos nacionais de desenvolvimento econômico, elaborados e executados nos anos de 1950 a 1980 , foram realizados sete amplos estudos sobre o sistema portuário nacional, que resultaram na produção de diversos planos portuários, comandados a partir dos interesses nacionais. Os planos respeitavam a hierarquia portuária, deixando de lado muitos portos regionais, como, por exemplo, o de Itajaí, que não foi incluído nos três primeiros pla- 
nos. Apesar de o porto de Laguna ser incluído no Plano Portuário Nacional de 1960-1962 e no de 1963-1966, com previsão para gastos para expansão e melhoramentos, nada foi realizado no período.

Já em relação a Santa Catarina, se até 1945 poderíamos olhar para o Estado com uma economia especializada, nos anos seguintes esta realidade começou a se alterar substancialmente. No período 1945-1962, assiste-se, na economia catarinense, a uma verdadeira diversificação e ampliação da base produtiva. Há uma diversificação porque surgem novos setores, como o de papel, papelão, pasta mecânica, cerâmico, metal-mecânico, materiais elétricos e indústrias ligadas ao setor de transporte. Há uma ampliação porque: a) os setores como o de papel, papelão, pasta mecânica, móveis e metal-mecânico, que nasceram antes ou nos anos de 1930, aumentaram a sua produção e também surgiram novas indústrias; b) os setores carbonífero e têxtil ampliaram a capacidade produtiva; c) e a agricultura começou a se industrializar, transitando do complexo agrocomercial para o agroindustrial. Os setores com potencialidades mais dinâmicas, o metal-mecânico, o cerâmico e a produção de papel e pasta mecânica, nascem da pequena produção e voltam-se para o mercado nacional, expandindo-se rapidamente, num momento em que a industrialização pesada estava num processo acelerado de expansão e consolidação. Porém, a pauta de exportação catarinense era composta em torno de $\mathbf{7 0 , 0} \%$ de madeira. As novas mercadorias produzidas em Santa Catarina (azulejos, papel, peças e equipamentos) eram destinadas basicamente ao mercado interno (GOULARTI FILHO, 2002 ).

O padrão de crescimento da economia catarinense alterou-se a partir de 1962, com a criação de um novo sistema de crédito estadual, com os investimentos em energia e transporte, comandados pelo Estado, e com a consolidação do setor eletro-metal-mecânico, liderado pelas médias e grandes indústrias. Mesmo nos setores tradicionais, várias firmas se consolidaram, incorporaram outras marcas, tornando-se líderes nacionais. Internamente, o movimento geral da indústria catarinense passa a ser conduzido por grandes e médias empresas nos setores de alimentos, eletro-metal-mecânico, cerâmico, têxtil-vestuário, papel e celulose, madeireiro, carbonífero, moveleiro, plástico e de porcelanas e cristais. A mudança do padrão de crescimento em Santa Catarina só pode ser entendida, em primeira instância, pela mudança do padrão de 
acumulação em nível nacional, que tinha como tripé básico o capital estatal, o externo e o nacional. Em 1962, começa um novo período em Santa Catarina, quando o capital industrial passa a ser o móvel da acumulação capitalista. A modernização da agricultura, com a mutação do complexo agrocomercial para o agroindustrial de carne, reforça e consolida o novo padrão de crescimento em Santa Catarina, comandado pelo Estado e pelas grandes e médias indústrias e agroindústrias (GOULARTI FILHO,2002).

Para atender às exportações da economia catarinense, nos anos de 1970 e 1980, foram aparelhados três portos: São Francisco do Sul, especializando-se em granéis, como uma extensão do complexo agroindustrial de carnes; o porto de Itajaí, especializando-se em cargas gerais e congelados e o porto de Imbituba, fortalecendo a sua especialidade no transporte de carvão. Os três portos se modernizaram em paralelo à integração e à consolidação da indústria catarinense. Em compensação, o porto de Laguna não acompanhou, no mesmo ritmo, a dinâmica da economia catarinense. Portanto, estava fora dos planos dos governos estadual e federal transformar Laguna num porto de carga.

A criação da Portobrás como empresa holding, em 1975, fortaleceu o sistema portuário brasileiro, que recebeu vultosos investimentos, sobretudo os portos que faziam parte dos corredores de exportações de produtos minerais e agropecuários (no sul do Brasil, apenas Rio Grande e Paranaguá). Nesta mesma época, começou a se expandir rapidamente o transporte de cargas conteinerizada, o que exigia uma ampla reestruturação nos portos brasileiros para se adaptarem ao novo sistema (PEIXOTO, 1977). Ambos, corredores de exportação e cargas conteinerizadas, estavam fora das possibilidades do porto de Laguna.

\section{Porto pesqueiro: uma solução paliativa}

Depois de seguidas tentativas frustradas para reerguer o porto de Laguna, finalmente em 1969 foi oficializada a sua transformação em porto pesqueiro. O Decreto-Lei $\mathrm{n}^{\circ} 525$, de 8 de abril de 1969, criou a Companhia Porto de Pesca de Laguna, uma sociedade de economia mista subordinada a DNPVN. Na verdade, este decreto apenas oficializou a transformação do porto de Laguna num porto pesqueiro estatal, pois o desembarque da pesca da região já vinha sendo feito no porto, 
faltavam as infra-estruturas necessárias e o sistema de vigilância. A criação do porto pesqueiro estava dentro dos planos da SUDEPE (Superintendência para o Desenvolvimento da Pesca), nos anos de 1970, que almejava ampliar a produção de pescados no Brasil, por meio de incentivos, financiamento e infra-estrutura.

Em 1971, o DNPVN, em consonância com a SUDEPE, elaborou o projeto do "Porto Pesqueiro de Laguna", que fazia uma análise retrospectiva da produção pesqueira em Santa Catarina, do mercado, das zonas de captura, da previsão da frota, do setor industrial e da organização administrativa e operacional, além de apresentar um plano diretor e o projeto para a construção da fábrica de gelo e do entreposto frigorífico (MINISTÉRIO DOS TRANSPORTES, 1971).

A principal obra a ser realizada, prevista no plano diretor, era a construção da fábrica de gelo e a do entreposto frigorífico.As obras começaram somente em 1973, com a retirada dos trilhos do cais, porém foram paralisadas no ano seguinte. Somente em 1979, com a inclusão de Laguna no Plano Diretor Portuário do Brasil, foram retomadas as obras (MINISTÉRIO DOS TRANSPORTES, 1979). E, finalmente, após dez anos de espera e de muita "choradeira", o porto pesqueiro de Laguna, administrado pela Portobrás, foi inaugurado no dia 15 de fevereiro de 1980 (GUEDES JÚNIOR, 1994). Como os barcos pesqueiros litorâneos têm baixo calados, não seria necessário fazer melhoramentos na barra de entrada. Além disto, como não foi resolvido o grande problema do porto, ou seja, não foi feito o desassoreamento no canal de entrada, a solução encontrada para Laguna foi transformá-1o num porto pesqueiro local. A expectativa era de que se desenvolvesse na cidade uma dinâmica indústria pesqueira, no entanto, dada a baixa acumulação de capital e a falta de comando industrial local, esta foi mais uma esperança frustrada para a população lagunense.

No início do governo Collor, em março de 1990, foi editada a Medida Provisória $\mathrm{n}^{\circ} 151$, que extinguiu e dissolveu cinco autarquias, oito fundações, três empresas públicas e oito sociedades de economia mista. Entre as empresas, estava a Portobrás. Após 70 anos de ampliação das funções institucionais dos diversos órgãos que foram criados para gerenciar os portos brasileiros, desde a IFPRC, numa simples medida provisória, foi desmontada toda a estrutura da Portobrás. Para os portos brasileiros, a extinção da Portobrás marcou o início de uma confusão 
administrativa e uma rápida deterioração das estruturas. Mais do que o sistema portuário, o governo Collor pôs fim às políticas de transportes, inclusive com a extinção do Ministério dos Transportes, que foi reduzido a uma Secretaria dentro do Ministério da Infra-Estrutura.As obras foram paralisadas, as licitações, suspensas e os projetos, encerrados. No quadro funcional dajá extinta Portobrás, a situação foi de espanto e de expectativa com o que viria pela frente após a absurda façanha.

Com a extinção da Portobrás com o porto de Itajaí, a administração do porto de Laguna foi transferida, em janeiro de 1991, para a Companhia Docas do Estado de São Paulo (CODESP), que praticamente manteve o porto sem nenhum investimento por 10 anos. A situação tornou-se ainda mais cática com o fim da SUDEPE, em 1989, e das políticas de incentivos à pesca.

A situação do porto de Laguna ainda continua quase a mesma, porém parece que o problema na entrada da barra, causado pela curvatura do molhe sul, será resolvido. Com base nos estudos realizados pelo Instituto Nacional de Pesquisas Hidroviárias, em 1990, que prevê a retificação e o prolongamento do molhe sul, e nos recursos liberados, da ordem de 4 milhões de reais, em 1998, no início de 2000 foram "recomeçadas" as obras na barra (COMPANHIA DOCAS DO ESTADO DE SÃO PAULO, 2003 ). Também será duplicada a capacidade da produção de gelo, automatizados os silos manuais, construídos dois salões de recepção de pescado e recuperado e arrendado o frigorífico para a iniciativa privada (COMPANHIA DOCAS DO ESTADO DE SÃO PAULO, 2004). Após a conclusão das obras na entrada da barra, será possível receber navios de grande calado que praticam a pesca oceânica.

As instalações portuárias atualmente são as seguintes: área portuária de $245.900 \mathrm{~m}^{2}$, cais acostável de 300 metros e calado de 6,5 metros, fábrica de gelo com capacidade de 50 toneladas por dia e dois salões de recepção de pescados, além de duas empilhadeiras com capacidade para $1,8 / 3,5$ toneladas e uma paleteira, com capacidade para 1,2 toneladas.

\section{Considerações finais}

O porto de Laguna andou sempre a reboque das estratégias nacionais, nunca houve um movimento endógeno que permitisse uma ampliação mais consistente nos seus serviços portuários. Primeiro como 
porto das conquistas no Brasil meridional, depois como porto da colonização, porto carvoeiro e, por último, dentro dos objetivos da SUDEPE, como porto pesqueiro. Os determinantes da falta deste movimento endógeno residem no fraco desempenho industrial em Laguna. Atualmente, a economia do sul de Santa Catarina conta com uma base industrial diversificada, pautada em indústria cerâmica, matérias plásticas, vestuário, metal-mecânico, molduras e química. Porém, as mercadorias destinadas a mercado externo são escoadas, em larga medida, pelo porto de Itajaí. Com a transformação em porto pesqueiro, gerou uma expectativa positiva de que se iria desenvolver na cidade uma dinâmica indústria pesqueira, no entanto, dada a baixa acumulação de capital e a falta de comando industrial na base econômica da cidade de Laguna, esta foi mais uma esperança frustrada para a população local.

Tomando como referência o ano de 1905 , quando foram iniciadas as obras de melhoramento pela Comissão dos Portos de Santa Catarina e observado o movimento da longa duração no porto de Laguna, no século XX, é possível identificar cinco períodos, destacando a evolução estrutural, a movimentação de carga e a administração: a) 1905 a 1939 neste período, destacam-se as incertezas e as dúvidas em relação ao projeto original de Calheiros da Graças e do método H. C. Ripley, que, ao longo da construção, se mostravam falhos. O porto ainda servia como escoadouro da produção agrícola das colônias do sul e do carvão. O porto de Laguna era um reflexo do padrão de crescimento da economia catarinense, baseado na pequena produção e no capital mercantil; b) 1939 a 1945 - durante a Segunda Guerra, Getúlio Vargas de cretou que Laguna seria o porto carvoeiro do país e para tanto foi construído um novo e amplo porto. Na disputa com o porto de Imbituba, Laguna saiu ganhando; c) 1945 a 1969 - nesse momento, na contramão da economia catarinense, que ampliava a sua base produtiva e se diversificava, o porto de Laguna perdeu o status de porto carvoeiro para Imbituba e agonizou no isolamento. Aos poucos, o transporte de cabotagem foi-se reduzindo e os barcos pesqueiros começaram a ocuparo porto; d) 1969 a 1980 - com o objetivo de recuperara economia local, especializando-se na pesca, a exemplo de outras regiões catarinenses que se especializavam em determinado segmento, em 1969 , o porto foi declarado pesqueiro. Porém, novamente o ritmo da construção foi lento e incompleto; e) pós-1980 - nesse período, destaca-se 
apenas a pesca, mesmo com os problemas na entrada da barra e a falta de infra-estrutura necessária para um bom desempenho. A criação do porto pesqueiro não resolveu o problema econômico local, pois não desenvolveu na cidade uma atividade pesqueira integrada com o porto e com a implantação da indústria da pesca, a exemplo de Itajaí.

Laguna foi o porto das expedições para o sul da Colônia, o porto da colonização do sul catarinense, o porto carvoeiro do Brasil e o porto pesqueiro de Santa Catarina. Apesar de toda turbulência, o porto pesqueiro de Laguna ainda resiste.

\section{Fontes e referências bibliográficas}

AVÉ-LALLEMANT, Robert. Viagens pelas províncias de Santa Catarina, Paraná

e São Paulo (1858). Belo Horizonte: Itatiaia; São Paulo: Editora da USP, 1980, pp. $35-36$.

BRASIL. Decreto $n^{\circ} 2,737$, de 6 de fevereiro de 1861. Coleção de Leis do Império do Brasil de 1861. Rio de Janeiro:Tipografia Nacional, tomo XXIV, parte II, 1861. Disponível em 〈http://www.camara.gov.br $>$. Acesso em 30 maio 2005.

Decreto $n^{\circ} \mathbf{5 . 9 0 1}$, de 17 de abril de 1875. Disponível em < $\underline{\text { 18tp:// }}$ www.senado.gov.br/servIets $>$. Acesso em 11 abril 2005.

. Decreto $n^{\circ} \mathbf{1 . 0 3 4}$, de 14 de novembro de 1890. Disponível em < $\underline{\text { http:// }}$ www.senado.gov.br/servlets $>$. Acesso em 11 abril 2005.

Decreto $n^{\circ} 271$, de 31 de dezembro de 1894. Disponível em < $\underline{\text { http:// }}$ www.senado.gov.br/servlets $>$. Acesso em 11 abril 2005.

.Decreto $n^{\circ} \mathbf{2 . 2 2 9}$, de 6 de fevereiro de 1896. Disponível em < http:// www.senado.gov.br/servlets $>$. Acesso em 11 abril 2005.

.Decreto no 18.281, de 15 de junho de 1928. Disponível em < $\underline{\text { http:// }}$ www.senado.gov.br/servlets $>$. Acesso em 11 abril 2005.

Decreto n $^{\circ} \mathbf{2 4 . 4 1 4}$, de 19 de junho de 1934. Disponível em < $\underline{\text { http:// }}$ www.senado.gov.br/servlets $>$. Acesso em 11 abril 2005.

Decreto no 2.794 , de 25 de junho de 1938. Disponível em < $\underline{\text { http:// }}$ www.senado.gov.br/servlets $>$. Acesso em 11 abril 2005.

Decreto $n^{\circ} 4.676$, de 16 de setembro de 1939. Disponível em < $\underline{\text { http:// }}$ www.senado.gov.br/servlets>. Acesso em 11 abril 2005.

. Decreto-Lei $n^{\circ} \mathbf{5 . 4 6 0}$, de 5 de maio de 1943. Disponível em < $\underline{\text { http:// }}$ www.senado.gov.br/servlets $>$. Acesso em 11 abril 2005.

.Decreto-Lei $n^{\circ} \mathbf{8 . 8 4 8}$, de 24 de janeiro de 1946. Disponível em <http:// www.senado.gov.br/servlets>. Acesso em 11 abril 2005.

. Medida Provisória $n^{\circ} 151$, de 15 de março de 1990. Disponível em http://www.senado.gov.br/servlets.Acesso em 18 de ago. 2004. 
BRASIL Relatório do Ministério da Indústria, Viação e Obras Públicas, . apresentadoaoPresidentedaRepúblicapeloengenheiroAntonioOlyntho

dos Santos Pires, em maio de 1895. Rio de Janeiro: Imprensa Nacional, 1895. . Relatório do Ministério da Indústria,Viação e Obras Públicas.

Rio de Janeiro: Imprensa Nacional, 1902. . Relatório...,op. cit., 1903.

- Relatório..., op. cit., 1904.

- Relatório..., op. cit., 1907.

- Relatório..., op. cit., apresentado ao Presidente da República pelo

Ministro José Barbosa Gonçalves, 1913.

. Relatório..., op. cit., apresentado ao Presidente da República pelo

Ministro Augusto Tavares de Lyra no ano de 1917, 1918.

Relatório..., op. cit., apresentado ao Presidente da República pelo

Ministro Maurício Joppert da Silva em 1946. Rio de Janeiro: Serviço de

Documentação, 1946.

BICALHO, Lucas."Comissão de Estudos e Obras dos Portos de Laguna e Imbituba:

Porto de Laguna". In MINIS TÉRIO DAVIAÇÃO E OBRAS PÚBLICAS. Re latório da Inspetoria Federal de Portos, Rios e Canais dos serviços prestado no ano de 1924 apresentado ao Ministro pelo Inspetor Federal Hidelbrando de Araújo Góes. Rio de Janeiro: Imprensa Nacional, 1926.

CALHEIROS DA GRAÇA, Francisco. Estudos sobre a barra da Laguna. Rio de Janeiro: Tipografia de G. Leuzinger \& Filhos, 1882.

CABRAL, Oswaldo R. História de Santa Catarina. Florianópolis: Lunardelli, 1994.

CANO,Wilson. Raízes da concentração industrial em São Paulo. São Paulo: Hucitec, 1990.

CARDOSO DE MELLO, João Manuel. O capitalismo tardio: contribuição à revisão crítica da formação do desenvolvimento da economia brasileira. São Pau1o: Brasiliense, 1988 .

CARvalHo, Fernando Viriato de Miranda. Estudo de portos no Brasil: ensaio. Rio de Janeiro: Jornal do Commercio, 1930.

CASTRO,Antônio Barros de. Sete ensaios sobre a economia brasileira. Rio de Janeiro: Forense Universitária, 1980.

CEAG/SC. Evolução histórico-econômica de Santa Catarina: estudos das alterações estruturais (século XVII-1960). Florianópolis: CEBRAE/CEAG-SC, 1980.

COCQ DE OLIVEIRA. Luiz J. Le."Viagem de inspeção aos portos do Estado de Santa Catarina". In MINISTÉRIO DA VIAÇÃO E OBRAS PÚBLICAS. Relatório da Inspetoria de Portos, Rios e Canais dos serviços prestados no ano de 1923 apresentado ao Ministro daViação e Obras Públicas pelo Inspetor Hildebrando de Araújo Góes. Rio de Janeiro: Imprensa Nacional, 1925. COMPANHiA DOCAS DO ESTADO DE SÃO PAULO. Obras no Porto de Laguna. Laguna, 2003 (Folder). 
COMPANHiA DOCAS DO ESTADO DE SÃO PAUlo. Porto de Laguna. Laguna, 2004 (Folder).

COSTA, Francisco Isidoro Rodrigues."Província de Santa Catarina comarca de Santo Antônio dos Anjos Laguna". In DALL'ALBA, João Leonir. Laguna antes de 1880: documentário. Florianópolis: Lunardelli; Editora da Udesc, 1976.

CUNHA, Idaulo José. Evolução econômico-industrial de Santa Catarina. Florianópolis: Fundação Catarinense de Cultura, 1982.

DALL'ALBA, João Leonir. Imigração italiana em Santa Catarina: documentários. Florianópolis: Lunardeli, 1983.

DEPARTAMENTO NACIONAL DE PORTOS, RIOS E CANAIS. Porto de Laguna: relatório do engenheiro Colombo Machado Salles sobre os estudos em modelo reduzidos pelo Laboratorie Central d'Hydraulique de France. 17 Distrito de Portos, Rios e Canais: Laguna, 1957.

- Porto de Laguna: molhe sul. Laguna: 17 ${ }^{\text {a }}$ Distrito de Portos, Rios e Canais, 1962 .

DEPARTAMENTO NACIONAL DE PORTOS E VIAS NAVEGÁVEIS.Situação do Porto de Laguna. Informativo do Departamento Nacional de Portos e Vias Navegáveis, Rio de Janeiro, ano II, nº 10, novembro, 1966.

.Estudo em modelo reduzido do porto de Laguna. Rio de Janeiro: I N P H, 1967.

. "Inaugurado o modelo de Laguna". Informativo do Departamento

Nacional de Portos e Vias Navegáveis, Rio de Janeiro, ano III, $\mathrm{n}^{\circ} 17, \mathrm{ju} 1 \mathrm{ho} /$ setembro, 1967.

DRAIBE, Sônia Miriam. Rumos e metamorfoses: um estudo sobre a constituição do Estado e as alternativas da industrialização no Brasil 1930-1960. Rio de Janeiro: Paz e Terra, 1985.

FREITAS, Luiz Cláudio. "Vias de comunicação e meios de transportes no sul de Santa Catarina 1850-1950". In Anais do VI Seminário de Iniciação Científica da UNESC. Criciúma: UNESC, 2006.

FURTADO, Celso. Formação econômica do Brasil. São Paulo: Companhia Editora Macional, 1989.

GAFFRÉE, Lucas Candido."Estudos e projetos do porto de Laguna". In MINISTÉRIO DA VIAÇÃO E OBRAS PÚBLICAS. Relatório da Inspetoria Federal de Portos, Rios e Canais dos serviços prestado no ano de 1922 apresentado ao Ministro pelo Inspetor Federal Lucas Bicalho. Rio de Janeiro: Imprensa Nacional, 1924.

GÓES, Hidelbrando Araújo. Problemas Portuários. Rio de Janeiro: Inspetoria de Porto, Rio e Canais, 1930.

GORDILHO, Edgard. "Inspeção aos portos do Sul". In MINISTÉRIO DA VIAÇÃO E OBRAS PÚBLICAS. Relatório da Inspetoria Federal de Portos, Rios e Canais dos serviços prestados no ano de 1920 apresentado ao Ministro pelo Inspetor Federal Lucas Bicalho. Rio de Janeiro: Imprensa Nacional, 1922. 
GOUlarti Filho, Alcides. Formação econômica de Santa Catarina. Florianópolis: Cidade Futura, 2002.

."Melhoramento, reaparelhamento e modernização dos portos brasileiros: a longa e constante espera". Anais do XI Encontro Nacional de Economia Política.Vitória: SEP, 2006.

GRENHALGH, João Carlos. "Relatório apresentado ao Conselheiro do Ministério dos Negócios da Agricultura, Comércio e Obras Públicas pelo engenheirofiscal da Estrada de Ferro Dona Teresa Cristina em 1881". In BRASIL. Relatório apresentado à Assembléia Geral na Segunda Seção da Décima Oitava Legislatura pelo Ministro dos Negócios da Agricultura, Comércio e Obras Públicas Manuel Alves de Araújo. Rio de Janeiro:Tipografia Nacional, 1882. (Anexo ao relatório)

GUEDES J Ú N I R, Valmir. Porto da Laguna: a luta de um povo traído. Florianópolis: Editora do Autor, 1994.

KROETZ, Lando Rogério. As estradas de ferro de Santa Catarina 1910-1960. Curitiba: UFPR/Depto. de História, 1975.

LABORATOIRE CENTRAL D'HYDRAULIQUE DE FRANCE. Port de Laguna: étude sur modele réduit. Paris, mars, 1956.

LAGO, Paulo Fernando. Santa Catarina: a terra, o homem e a economia. Florianópolis: Ed. da UFSC, 1968.

LisboA, Alfredo. Portos do Brasil. Rio de Janeiro: O Norte, 1922.

MilaneZ, Pedro. Fundamentos históricos de Criciúma. Florianópolis: Ed. do Autor, 1991 .

MINISTÉRIO DA VIAÇÃO E OBRAS PÚBLICAS. Relatório da Inspetoria Federal de Portos, Rios e Canais dos serviços prestados no ano de 1927 apresentado a Ministro pelo engenheiro Hidelbrando de Araújo Góes. Rio de Janeiro: Jornal do Comércio, 1928.

Relatório do Departamento Nacional de Portos e Navegaça dos serviços executados em 1936, apresentado ao Ministro pelo diretor Frederico Cezar Burlamaqui. Rio de Janeiro: Gráfica do DN PN, 1937. . Relatório..., op. cit., serviços executados em 1938, apresentado ao Ministro da Viação e Obras Públicas pelo diretor Frederico Cezar Burlamaqui. Rio de Janeiro: Gráfica do DNPN, 1939.

. Relatório dos serviços executados no ano de 1939 pelo Departamento Nacional de Portos e Navegação, apresentado ao Ministro daViação e Obras Públicas João de Mendonça Lima pelo Diretor Frederico Cezar Burlamaqui. Rio de Janeiro: Imprensa Nacional, 1940. . Relatório... ano de $\mathbf{1 9 4 0 . . . , ~ o p . ~ c i t . , ~} 1941$. .Relatório... ano de $1941 \ldots$, op. cit., 1943. . Relatório... ano de $\mathbf{1 9 4 2 . . . , ~ o p . ~ c i t . , ~} 1944$.

. Relatório do Departamento Nacional de Portos, Rios e Canais dos serviços executados em 1945, apresentado ao Ministro daViação e 
Obras públicas pelo Diretor Geral Clovis Macedo Cortes. Rio de Janeiro: Imprensa Nacional, 1949.

MINISTÉRIO DA VIAÇÃO E OBRAS PÚBLICA Relatórios de Atividades do Departamento Nacional de Portos e Vias Navegáveis 1965. MVOP: Rio de Janeiro, 1965.

Ministério Dos transportes. Porto pesqueiro de Laguna. Rio de Janeiro: DNPVN,v.2,1971. .plano Diretor Portuáriodo Brasil: Portode Laguna. Brasília: Portobrás, 1979.

MORAES Eduardo José de. Canal da Junção da Laguna a Porto Alegre: memória justificativa de seu projeto. São Paulo: Tipografia de Jorge Seckler, 1879.

MORAES, Fabio Farias. "O carvão catarinense e o planajamento estatal". In GOULART I FILHO, Alcides (org).Ensaios sobre a economia sul-catarinense. Criciúma: Editora da UNESC, 2003.

PEIXOTO, João Baptista. Os transportes no atual desenvolvimento do Brasil. Rio de Janeiro Editora Biblioteca do Exército, 1977.

PIAZZA, Walter F. A colonização de Santa Catarina. Florianópolis: Lunardelli, 1994.

VIEIRA.J. D. Belfort."Porto de Laguna". In Minis TÉRIO DAVIAÇÃO E OBRAS PÚBLICAS Relatório da Inspetoria Federal de Portos, Rios e Canais dos serviços prestado no ano de 1922 apresentado a Ministro pelo Inspetor Federal Lucas Bicalho. Rio de Janeiro: Imprensa Nacional, 1924.

SAES Flávio Azevedo Marques. A grande empresa de serviços públicos na economia cafeeira 1850-1930. São Paulo: Hucitec, 1986.

SAINT-Hilaire, Auguste de. Viagem a Curitiba e província de Santa Catarina. Belo Horizonte: Itatiaia; São Paulo: Editora da USP, 1978.

SANTA CATARINA.Fala do presidente da Província de Santa Catarina José Joaquim Machado de Oliveira na abertura da Legislatura Provincial em março de 1837. Cidade do Desterro:Tipografia Provincial, 1837. Disponível em <http://wwwvcrl.uchicago.edu>. Acesso em 30 maio 2005.

. DiscursopronunciadopelopresidentedaProvínciadeSanta

Catarina Brigadeiro João Carlos Pardal na abertura da Assembléia Legislativa em 1839, Cidade do Desterro:Tipografia Provincial, 1S39. Disponível em <http://wwwcrl.uchicago.edu>. Acesso em 30 maio 2005.

TAVARES, Maria da Conceição. Acumulação de capital e industrialização no Brasil. Campinas: U N I C A M P/IE, 1998. 
Anexo 1 - Movimento de carga e navios no porto de Laguna 1917-1970

\begin{tabular}{|c|c|c|c|c|}
\hline ANO & EXPORTAÇÃO (T) & CABOTAGEM (t) & TOTAL (t) & TOTAL (navios) \\
\hline 1917 & - & 21.279 & 21.279 & 221 \\
\hline 1918 & - & 15.773 & 15.773 & 173 \\
\hline 1919 & . & 18.731 & 18.731 & 226 \\
\hline 1920 & - & 24.770 & 24.770 & 229 \\
\hline 1921 & - & 24.846 & 24.846 & 194 \\
\hline 1922 & 208 & 21.470 & 21.678 & 187 \\
\hline 1923 & - & 28.844 & 28.844 & 245 \\
\hline 1924 & 543 & 32.682 & 32.225 & 182 \\
\hline 1925 & 307 & 32.888 & 33.195 & 173 \\
\hline 1927 & 186 & 29.241 & 29.427 & 182 \\
\hline 1928 & 157 & 33.201 & 33.353 & 134 \\
\hline 1930 & 93 & 26.281 & 26.374 & 185 \\
\hline 1931 & 211 & 26.530 & 26.741 & 159 \\
\hline 1932 & 43 & 31.414 & 31.457 & 167 \\
\hline 1933 & 134 & 21.191 & 21.325 & 143 \\
\hline 1934 & 86 & 25.643 & 25.729 & 168 \\
\hline 1935 & 746 & 21.274 & 22.070 & 167 \\
\hline 1936 & 3.104 & 28.307 & 31.411 & 150 \\
\hline 1937 & 176 & 27.142 & 27.318 & 160 \\
\hline 1938 & 24 & 25.633 & 25.657 & 144 \\
\hline 1939 & 23 & 34.561 & 34.681 & 150 \\
\hline 1940 & 905 & 48.244 & 49.582 & 174 \\
\hline 1941 & 16.078 & 148.180 & 164.258 & 343 \\
\hline 1942 & 1.199 & 183.358 & 184.767 & 347 \\
\hline 1943 & - & 178.917 & 178.817 & 327 \\
\hline 1944 & - & 208.207 & 208.207 & 333 \\
\hline 1945 & & 179.339 & 179.339 & 308 \\
\hline 1946 & 1.822 & 190.682 & 192.504 & 313 \\
\hline 1947 & 2.686 & 211.128 & 213.814 & 322 \\
\hline
\end{tabular}




\begin{tabular}{|c|c|c|c|c|}
\hline ANO & EXPORTAÇÃO (t) & CABOTAGEM $(\mathrm{t})$ & TOTAL (t) & TOTAL (navios) \\
\hline 1948 & 2.113 & 187.578 & 189.697 & 334 \\
\hline 1949 & - & 174.310 & 174.310 & 321 \\
\hline 1950 & - & 177.569 & 177.569 & 327 \\
\hline 1951 & - & 128.151 & 128.151 & 236 \\
\hline 1952 & - & 160.726 & 160.726 & 296 \\
\hline 1953 & - & 159.102 & 159.102 & 293 \\
\hline 1954 & - & 80.362 & 80.362 & 148 \\
\hline 1955 & 7.404 & 92.641 & 100.045 & 180 \\
\hline 1956 & 4.727 & 55.364 & 60.091 & 128 \\
\hline 1957 & 2.027 & 34.514 & 36.541 & 73 \\
\hline 1958 & 3.226 & 49.111 & 52.337 & 88 \\
\hline 1959 & 354 & 45.018 & 46.628 & 95 \\
\hline 1960 & 2.739 & 41.010 & 44.249 & 98 \\
\hline 1961 & 4.406 & 47.566 & 51.972 & 126 \\
\hline 1962 & 2.051 & 50.950 & 53.001 & 138 \\
\hline 1963 & 992 & 51.614 & 52.606 & 112 \\
\hline 1964 & - & 71.428 & 71.428 & 98 \\
\hline 1965 & 283 & 6.347 & 7.204 & 24 \\
\hline 1966 & - & 30.243 & 30.243 & 64 \\
\hline 1967 & 961 & 62.313 & 66.218 & 76 \\
\hline 1968 & 899 & 19.328 & 23.896 & 56 \\
\hline 1969 & - & 10.851 & 12.771 & 27 \\
\hline 1970 & & 1.628 & 1.628 & 5 \\
\hline
\end{tabular}

Fonte: Relatórios do Ministério da Viação e Obras Públicas; Inspetoria Federal de Portos. Rios e Canais; Departamento Nacional de Portos e Navegação; Departamento Nacional de Portos, Rios e Canais; Estatística dos Portos - Departamento Nacional de Portos e Vias Navegáveis.

Obs.: Os dados de cabotagem e total de 1950 a 1954 foram estimados com base na variação no movimento de navios. 